\title{
The Theoretical Proposition to Promote and Motivate Prison Labour in Ghana
}

\author{
Priscilla Brobbey \\ College of Distance Education (CoDE), University of Cape Coast, Cape Coast, Ghana
}

\begin{abstract}
The ultimate purpose of the prison industry over the years was for the incarceration of criminals to serve their custodial sentence, which was later fused with rehabilitation programs to reform criminals to become better citizens after being released from custodial sentences. However, the outcome of the reformation of convicts after released from the prison has been a sad story than expected success cases. Hence, the theoretical proposition of the paper with respect to the prison industry of Ghana is to resolve recidivism, promote inmates' skill upgrade and labour reformation programs to become socio-economic beneficial during and after a custodial sentence.
\end{abstract}

Keywords: Convicts, Prison Labour, Prison Industry, Rehabilitation, Recidivism.

\section{Introduction}

Labour is the most dynamic among the factors of production, while human capital is a term used to define the calibre of labour available for employment by an organization for the achievement of its goals for the benefit of the entire economy. Human capital is, therefore, the body of individuals with the required know-how, capacities, knowledge, and personal attributes that encourage the performance of tasks to create socio-economic values within an economy [1]. Education is known to be the most fundamental tool used for the development of human capital, which is the foundation of economic growth and development of many nations across the globe. Undoubtedly, one of the most beneficial investments in human capital is Education, and because of that [2] and other American economists of the early 1960s regarded expenditure on education as one of the major factors driving the swift growth of the American economy, with the assertion that a dollar investment in education generated sizeable swell in their country's GDP as juxtaposed to a dollar investment in tangible capital like dams, road, street light and the likes [3].

It has been established that education and training of human resource has a direct relationship with economic growth in all economies across the globe. A plethora of studies have discovered that a positive correlation exists between human capital development and economic growth and development of nations [3]. For that matter, it is an onus on the authorities of every country to invest heavily in education due to the fact that it is the foundation of the economic prosperity of all nations. Bangladesh scholars did assert that high public investment levels and advancement in institutional environments in Bangladesh would be useful for economic growth [4]. Indisputably, an economy derives its strength from the size and quality of human capital at its disposal. Hence, the strength of an economy and the number of educated people is directly related. Accordingly, the instrumental role played by human capital in an economy is determined by the enrollment rates of senior high school students in a country [1]. Human capital, being the most fundamental and dynamic resource among the factors of 
production, requires paramount attention from national authorities for its development - it is very important that national authorities make an investment in the education of their citizenry their topmost priority. An important recommendation is that governments should prefer more investment in human capital development to capital investment [5].

\section{Results of Empirical Studies on Human Capital and Economic Growth in Africa}

The positive relationship between human resource development and economic growth has been emphasized in other studies. For instance, the study of [6] investigated the contribution of diverse dimensions of human capital development to economic growth in Nigeria and employed data from Nigeria, and adopted the growth account model, which indicated an increase in economic growth as a function of labour and capital. The study discovered that both education and health dimensions of human capital development are pivotal to economic growth in Nigeria $[6,7]$. The magnitude of the contribution of human capital to GDP growth has been dichotomized. This presented a revelation that primary education contributes significantly to social development, but secondary education contributes little economic development, and higher education consumes a huge fraction of public and private purse to contribute negligibly to economic growth and development [7]. This study has encouraged the conduct of further studies into the relationship between education and economic growth so as to render the educational system more effective towards economic development.

Human capital remains indispensable in the quest to achieve economic growth and development [8], employed the endogenous growth model in the assessment of human capital development and economic growth in Nigeria. He made use of admission in the different echelons of education, which included primary, secondary, and tertiary as alternatives for human capital, and discovered an extensive positive relationship between human capital development and economic growth in Nigeria with a response procedure $[9,10]$. In a similar study, [11] used a panel data model entirely for advanced nations in the 1980-2005 duration. It was discovered that improvements in health had left substantial positive impacts on economic growth. Hence it should be regarded as a crucial element of human capital in tandem with education. The conclusion was that investing in the education and health of individuals is important for increasing economic growth and sustainable development $[10,11]$. In a similar vein, [12] conducted a study on the topic "Regional economic growth and human capital: the role of over-education" The researcher used various indicators of human capital computed from census microdata. The researcher concluded that the contemporary economic performance of European regions was related to an increase in over-education. Human resource development is fundamental to the socioeconomic wellbeing of Third World nations.

Therefore, it is an improved education that can pave the way for developing nations to enhance their long-term economic performance $[13,14]$. This implies that a positive correlation continues to exist between human capital development and economic progress in every economy. The positive relationship between the education of citizens and gross domestic product exhibited itself in the work of [15]. The researcher utilized the enhanced Solow humancapital-growth model to explore the impact of human capital development on national products, a proxy for economic growth, using quarterly time-series data from 1999-2012. The study revealed that human capital development had a substantial positive impact on output level when the Ordinary Least Square multiple regression model was applied, which was used to compute the impact of human capital development on the long-term economic growth of Nigeria. [10] observed that physical increase in school enrollment alone cannot propel economic growth. The study discovered 
that the elements of human capital development defined by the ratio of primary education enrollment, post-primary education enrollment, and tertiary education enrollment were positive but insufficient in promoting economic growth in Nigeria. The study therefore proposed for the rejuvenation of the Nigerian educational system.

\section{Prisoners Rehabilitation and Labour Assessment}

$[16,17]$ submit, correctional facilities have long experienced tensions between two missions of protecting public safety and rehabilitating offenders. [18] argued, the paradox of punishment and correctional approaches for behaviour change is as old as the correctional facilities globally. In the early $1,900 \mathrm{~s}$, the correctional field started using treatment approaches after many years of dehumanizing and brutal prison conditions. With the correctional officers referred to as prison guards. They further did argue that prior to 1956 , a guard had the role of maintaining security and international order. Indeed, the term 'guard' suggests a custodial identity. Hence the adoption of the latest title 'correction officer' reflects the introduction of the rehabilitative philosophy of the field of corrections as asserted by [18] in their research study of rehabilitation policies of the 1970s. They further argued, such an approach became a disaster causing trouble in the prisons in the middle of the 1970s. [19], equally came to a similar conclusion, said, nothing worked in offenders' treatment; hence, the sentencing landscape changed to 'get tough' laws, and the community corrections followed suit by moving back to surveillance and punishment models. In the 1990s, [20, 21] argued the 1970s approach of correctional models could not have been realistic because most of the punishmentoriented approaches were not effective. And most programs of that kind lacked treatment components, which actually enhanced recidivism as submitted by [21, 22]. [23], later argued that the role of the correctional officer as a service provider is likely to solidify in the near future rather than to dissipate in the correctional facilities, observing the situational report of the 1970s and beyond. [24, 25, 26] the outlined studies all point to a similar conclusion on the correctional facilities in Asia, America, and Europe are rapidly reforming their prisons so as to offer inmate rehabilitation, correctional counseling, and treatment services as opposed to punishment. All the outlined studies complemented each other in their central submission. Because of the number and influence of inmates, correctional officers are ideally to be placed on rehabilitating and influencing inmates positively. Which can mainly be done during frequent interaction. [18] established in their findings that officers with higher education were more likely to have positive attitudes towards rehabilitation and treatment programs. While [27] reported that women have more positive attitudes towards individual counseling than men do. Then [28], however, found a positive relationship between seniority and punishment orientation.

The paramount focus of this study is to strike a balance on how the inmate, whether professional or non-professionals in their custodial sentence, will go through rehabilitation without the loss of economic benefit of labour input to the national economy as a whole. Then after serving their custodial sentence, their access to the entrance of the open economic market to avoid or limit the stress involved, in other to reduce the circumstance resulting in recidivism. [29] argued imprisonment is the most expensive method of punishment in western countries as compared to other alternatives. She, therefore, submit how the States may use the human capital, which the prison accommodates to derive benefits from the inmates' work. She further holds the opinion that an efficient prison industry should provide better work opportunities and wages to inmates. A means for prisoners to partially cover their 
maintenance costs, improve their working skills, and enjoy meaningful activities during their punishment.

Therefore, the researcher theorizes that one of the feasible and effective ways to promote prison labour performance is an introduction to innovative and incentive mechanisms to encourage prisoners to be inspired to work productively in Ghana. She, therefore, assert, the incentive initiative has the capacity to influence and inspire private firms to offer the inmates employment and proper wages. Hence, this research seeks to explore in addition to its scope of the study by identifying other related avenues inmates may not only be viewed as criminals to serve their custodial sentence but as human capital which may contribute to their cost of incarceration and to some extent, contribute to the taxes paid from the prisoner's income and finally the ability to save some aspect of their generated income towards their day of release to become the start-up capital that will cushion them in their exposure to the open market to minimize the sense of difficulty and pressure in the market trading entrance. [29] posits work in prison is not a new notion for correctional institutions. Nevertheless, the stated goal of such policies is rarely the costeffectiveness of prisons. It is a notion that the work in prison prepares offenders for their life after release and is expected to increase their employment opportunities, even though there is scarce empirical support for increased employability and reduction of recidivism under the current structure of prison labour as argued by [30]. Shea further argued, according to the experience of the Prison labour structure of Europe. She said there are three main forms of prison labour. The first prison labour works consists of domestic duties, which are tasks performed for the daily maintenance of the prison. The second type of work is external contracts, in which the human prison capital is 'contracted out' to private companies, who pay the prisoners to produce products and services for them. And the third type of work is self- employment. Which she was quick to argue the option is rarely feasible in many environments to allow inmates under certain conditions to manage their own business. The researcher acknowledges that in most jurisdictions, prisoners are not considered as employees, and different labour laws are not applicable to them. In most cases, their salaries are usually considerably lower than the open market wages. [29] indicated the main type of labour performed in Dutch prisons is packing, printing, bookbinding, carpentry, metalwork, textile and fabrics, leather manufacturing. [31], in addition, stated, the Prison also offers some vocational training for "Welders, leather operators, Carpenters, Painters, and Bricklayers, etc. With the correctional Institutions bearing the burden of machinery and material costs. As the researcher has the interest to explore the capital of inmates in Ghana, [29] advice with an extensive study conducted on prison labour in England and Wales, France and Germany during the 2000s, identified obstacles to efficiency and productivity. Which she outlined as follows;

\section{Lack of Business Orientation and Organizational Weakness}

She observed, profit-making is not seen as a goal of the prison industry, and those who run the prisons lack the economic and business orientation. And frequently there is a lack of job opportunities. Furthermore, prison bureaucracies limit the available budget and prevent risky decisions, which are sometimes necessary for a business to develop and profit [30] pp.39-41.

\section{Low Levels of Productivity}

She observed, the level of productivity of the prison industry is significantly below the market, ranges between $15-40 \%$. This is attributed to the workers' personal characteristics. [30] pp.131-132 argued for other reasons as contributive factors, like poor incentive schemes to motivate the inmates to 
exert effort to increase productivity. The remuneration is too low. Secondly, due to the prison routine, the daily working hours of inmates are too short and often interrupted in their work for different reasons.

\section{The Prison Environment Effect}

The prison premises are often not suitable for production. The workshops are too small, and the apparatus lacks commercial qualifications, and is mostly out-of-date.

\section{Advancing Prison Labour Enterprise in Ghana}

The researcher makes the following proposition based on the objective understanding of the established empirical analysis of the negative socio-economic effect of the inmates of both professional and nonprofessional status incarceration in Ghana. Taken a wide observational study of the custodial sentence impact on the inmates' private and public life, as well as the economic consequences to their nuclear and extended family, and finally the national economy as a whole. Below are the proposed theories;

\section{Defining the Goal of Prison Industry in Ghana}

The researcher submits that to be able to increase the cost-serving conditions of the prison labour in Ghana, a clear goal of the prison industry should be established to guide in the improvement of the structure of the person. And further posit, if the prison industry will hold a primary goal of profitability, it will strengthen its labour market. However, the researcher issue caution, for the essence of paying critical attention to safeguard the inmates' human rights and avoiding any form of exploitation of prisoners and labour extraction. Therefore, with such a primary goal for prisons in policy-wise will provide meaningful activities to in-mate and ensure that working conditions are brought closer to those serving a custodial sentence. This has the probability of installing rehabilitation principle and improve the prisoner's perspective after release.

\section{Quality Incentive Scheme Initiative'}

The researcher put forward that the prison system of Ghana should uphold a PrincipalAgent relation. Where the prisoner is hired to advance the objective of the employer in return for a wage or other benefits. Per the economic approach, inmates, like other people, are utility maximizes and, under asymmetric information conditions, will try to avoid the effort when supervised or not be rewarded for performance. Appreciating the fact that constant monitoring of productivity of the workers is a costly method, it would be appropriate to institute sound incentives as compensation to the workers to fulfill the employer's goal.

\section{Parole Incentive Policy in Ghana}

The researcher proposes for another innovative incentive mechanism to enhance work productivity in prison. Which is a prisoner shall receive a right for an early release, as discretionary only in exchange for productive work. This stands to resolve the overpopulation problems faced in Ghana prisons, helping to reduce it and as well decrease reoffending situations through better rehabilitation and integration programs. Instituting competent parole policy, which may consider first-time incarcerated, to be released from custodial sentence after serving half (1/2) of the period for the punishment conditions. A recidivist situation as second-time incarceration may be paroled after completing two-thirds (2/3rd) of their custodial sentence. Including other reasonable parole policy incentives to guide the promotion of work productivity in prison. While such release could also be accompanied by a mandatory post-release supervision period monitored by a probation officer of the prison to monitor prisoner's release under parole policy and assess performance for judgment of release or not. However, caution is raised on parole policy, it has to be transparent in a 
calculation, realistic to productivity, and clearly communicated to the prisoner prior to the commencement of the work.

\section{Payment Scheme Initiative}

The researcher posits a well-structured payment scheme has the propensity to induce prison workers to exert effort to minimize the monitoring or supervisory cost. Under such a scheme, the wage of the inmates as a worker is directly correlated with productivity. But should be practiced with a cautionary measure. This scheme is not appropriate in an environment where output production is very hard to measure. However, the adoption of a piece-rate-pay system is very conducive to the environment that inmates engaged are more skilled and have a strong work motivation. It even becomes an added advantage by looking at the job experience and education as a consideration to utilize the prisoners' capacity and productivity. This kind of model wages allows prisoners to contribute to income tax to the government and assist to some extent their maintenance fee at the custody.

\section{Prisons \& Private Joint firm Incentive Initiative}

The researcher asserts with the observation that the managers and owners of private agencies are mostly profitable driven Institutions. Therefore, it is of utmost relevance for the prison institution to structure a system of incentives, which will make the employment of prisoners beneficial for those corporations. It has to be acknowledged, the mere appeal to the social desirability of cooperation with prisons will not be enough to induce firms to contract prison labour if it is not profitable. With a subject to the Ghanaian environment, the researcher further proposes, since the cost of prison labour is less costive than the open market, this could easily become a promotional strategy to attract private agencies for such services in other to have a competitive open market price for trading products. Secondly, to help reduce recidivism, the government could intervene with social entrepreneur initiative with special stamps of recognition and awareness to those private companies engaging prison labourers for the public patronization, indicating that such an exercise helps to reduce the burden of the tax-payers to the prisons and provide the inmate with the opportunities to assist in financing their custodial sentence. Furthermore, as an advantage in a reduction of crime. Thirdly, the government could have a joint-private venture initiative program, where both public and private agencies engage prison workers with outlined legal procedures by the government of hiring and firing prison workers engaged for production or services, including necessary compensation insurance. In the presentation of all these theoretical propositions in favour of prison labour contribution for socio-economic impact. There are cautionary factors to be considered for realistic output, which the researcher argues as follows taken into consideration the Ghanaian environment;

For the prison industry to be successful to restructure its labour for profitability requires the manager of the prison to be personnel of management and business orientation background. It will help the officer to easily understand the open market, to adjust when necessary to its dynamics and the changing demands. And in addition, such kind of office remuneration should be attached to the productivity of the prison work in other to incentivize such officer to make better decisions. Secondly, the researcher recommends, to be able to maintain the profitability of the prison industry in Ghana without endangering the other goals of the prison. Structural management could be grouped into two categories. The professionals manage the profitability agenda of the prisons, and the public officers manage the security goal of the prison to ensure a proper balance.

Even though the idea of prison labour is not contested in most countries including Ghana and widely implemented. However, there is a 
resistance in setting profit as the main goal for prison labour. Which its explanation of objection is mostly found in social, legal and political motives. If such motives will be carefully contested in favour of opportunities, which the prison labour offers as a benefit to government and tax-payers of both short- and long-term run. And also, as a means to prepare inmates to qualify for future employment.

\section{Open Market Entrance Model Proposal for Ex-Convict}

The researcher opted to rely on the design of an organogram or organizational chart on this level of conjecture and analysis as a symbol language for the proposed structure underlying the effective procedure in introducing exconvict to the open business market to minimize stigmatization and recidivism. This chart design method was adopted as appropriate means of the researcher argument on this subject matter in reference to the assertion of [32], which state, such method helps to establish the framework of the relations in jobs, systems, operating process, people, and groups, making efforts to achieve the goals. It also makes it easy to coordinate the activities of work factors and control the members' actions [33].

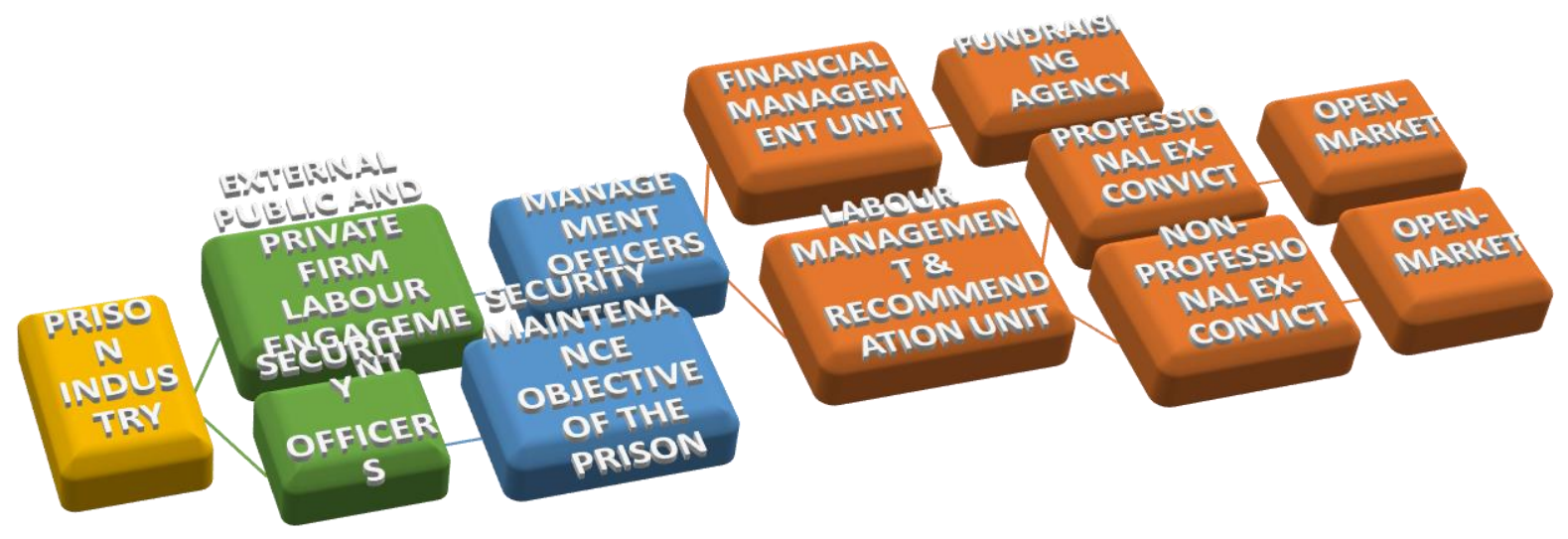

P. Brobbey, 2020

Figure 1. Model Structure for the Prison and the Open Market for the Release of Ex-Convict 


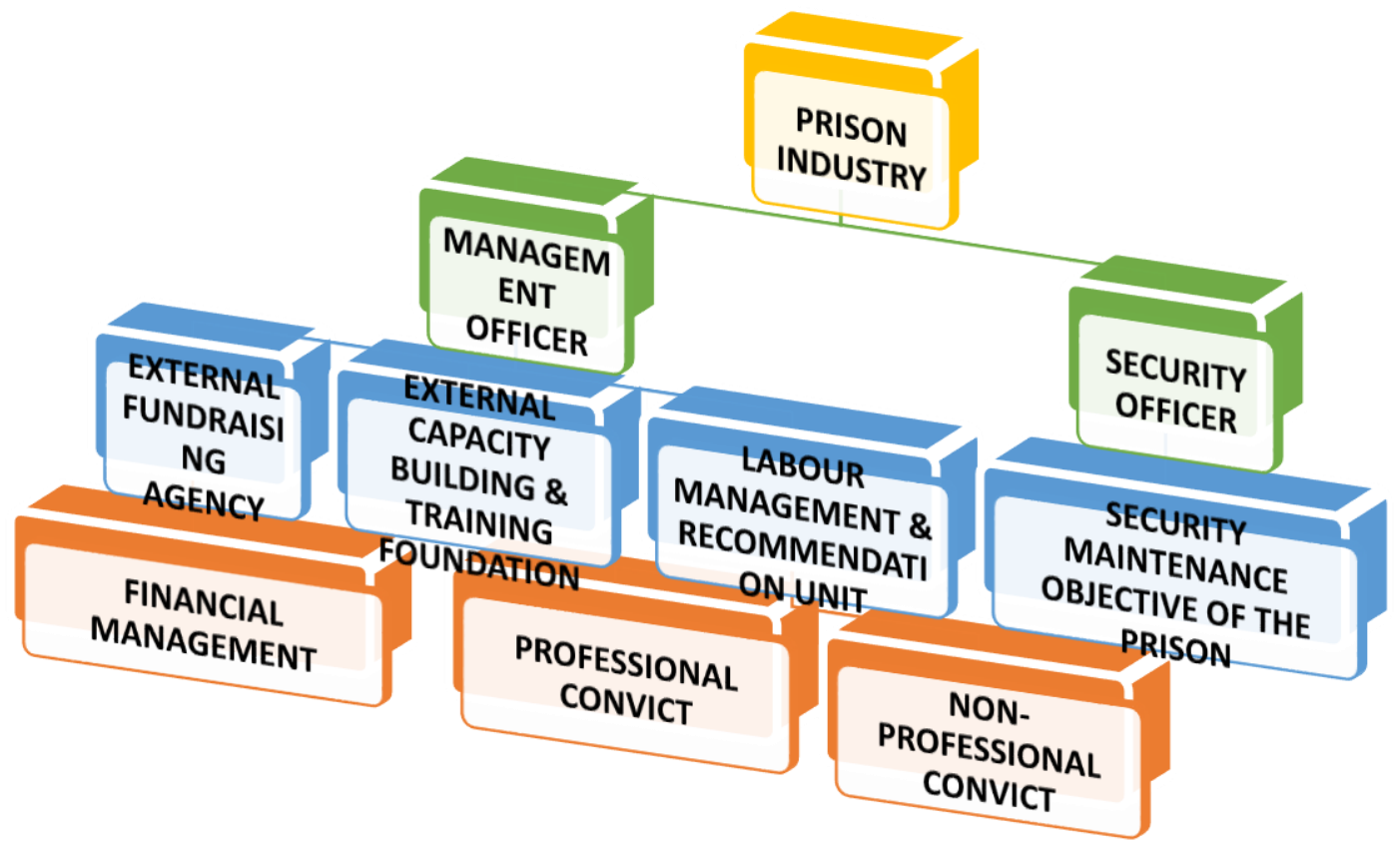

P. Brobbey, 2020

Figure 2. Rehabilitation Structure for Convict: Inside Skill Acquiring Support Model

While Figure 1 places emphasis on the active role of the management department of the Prison Industry to have a firm control on its Labour management and recommendation unit to assist ex-convict both the professionals and non-professionals to easily connect to the open industrial market with ease and less or no stigmatization. Figure 2 places a special focus on the managerial offices of the Prison industry to establish its capacity building and training foundation on accredited educational agencies to equip and enhance the knowledge skill of the inmates as a preparation towards their release and integration to the open market.

The sharp difference between Figure 1 and Figure 2 under the prison industry is that Figure 1 takes a deep focus on how the internal structure of the prison operational framework on its role as a rehabilitation center should create a strong bridge between the prison economy and the open industrial economy to strengthen the experience and skills orientation impacts of inmates towards their official release from their custodial sentence as ex-convicts, in other to integrate smoothly to the open market to reduce recidivism. While that of Figure 2 establishes its focus in the internal prison management affairs of inmates' skill development and improvement capacity relevant to revenue generation for the prison industry to reduce government expenditure as a cost burden to the taxpayer and secondly, not obsolete when officially allowed to integrate to the open market as ex-convicts.

\section{Materials and Methods}

Qualitative method and phenomenological approach were adopted for the study. The researcher obtained qualitative data from primary sources through interviews. The sample comprised 160 prisoners selected through purposive sampling technique. The purposive sampling technique assured the researcher that participants had the ability to disclose their personal experiences in the phenomenon under investigation.

Prior to the interview, the researcher contacted the authorities of the Prisons Service in Ghana to obtain information about the categories of prisoners being. The researcher 
delivered three copies of the written consent form. The first copy was sent by post for their perusal, prior to the interview. The other two copies were signed by participants who agreed to take part in the interview. Both the researcher and each participant kept a copy of the signed consent form.

Each interview was initially slated to take between 50 and 60 minutes but ended up being two hours. The interviews took place at the prison premises of each participant. The researcher met each of the participants, briefed them on the study and clarified what was required of participants and their right to withdraw from the study. The researcher used four days to contact all participants enquire about their convenient times for the interviews. The researcher strictly kept to the appointment booked with each participant in carrying out the interview. The researcher conducted the interviews personally using a recorder and notepads. Each respondent was asked to verify the correctness of the summarized version of his/her responses and requested to go through to confirm the accuracy of their submissions in the interview.

Codes, instead of individual names, were used to safeguard the identity and the rights of participants. The one hundred and sixty imprisoned participants were assigned the following pseudonym: $\mathrm{ABC} 1, \mathrm{ABC} 2, \mathrm{ABC} 3$, $A B C 16$. This guaranteed confidentiality of the identity and responses of the participants. Finally, the responses were analysed qualitatively.

\section{Results}

The theme, human capital development and utilization, as derived from the data obtained from the participants reflected the magnitude of the impact of incarceration of criminals on the rate of human resource development and its usage for economic progress. All participants described the imprisonment of perpetrators of crime as a factor that militated against the smooth development of human capital. They regarded imprisonment as an impediment to realisation of the full potential of the benefits of human resources of convicts. They outlined reduction in human capital, reduction in vocational training experts and rise in unemployment among the youths. The following were the opinions of the participants with regards to the impact of imprisonment on human capital development.

$\mathrm{ABC}$ 72: My imprisonment has caused a reduction in the supply of labour by one person as well as one competency or skill under the human capital have been lost.

ABC 68: Underutilized professional teaching skills - I am now rendering my services at the basic level to inmates and not to the larger society in terms of human capital.

Participant ABC 73 held a different view about the notion that human capital was being underutilised. He claimed that although his incarceration had impacted the health sector negatively in the larger society, he had been able to use his knowledge to develop human capital in the prisons by teaching other inmates.

ABC 43 My imprisonment and my eventual involvement in the education sector have afforded the inmates an opportunity to build a career. This will increase availability of human capital in Ghana. My imprisonment will improve the health system in the prisons.

Not with standing, my imprisonment has also affected the health system in my community by reducing the number of available medical doctors.

\section{Reduction in Active Labour}

Participants described their imprisonment as one of the ways of robbing the economy of productive labour. They asserted that this situation was injurious to the development of the economy. Some of them emphasised that if this situation continued, the government would pay dearly for it by incurring the cost of training other citizens to replace the incarcerated professionals. Other participants claimed that this situation had dire 
consequences for both the government and the economy in general.

ABC 60: My imprisonment has reduced the number of practicing nurses by one and this has a negative effect on the development of human capital.

$A B C$ 61: My imprisonment has reduced, by one, the number of patriotic, able-bodied officers who should have by now administered justices and served the country. This costs the government time and other resources to retrain someone else to occupy my position.

However, participants $\mathrm{ABC} 42$ and $\mathrm{ABC} 57$ expressed a different opinion about the assertion that imprisonment of people could lead to reduction in active labour. They claimed that their services were critically needed in the prison. These participants claimed that they put their profession at the disposal of other prison inmates. Participant ABC 42 claimed that he had been teaching his co-inmates Religious and Moral Education while ABC 57 emphasised that she had never been idle in the prison because there was high demand for health services in the prison yard. These were how they presented their experiences:

$A B C$ 52: My contribution as a teacher, religious leader and facilitator to my co-inmates in the prisons is gainful to the government.

ABC 57: Government now stands to gain from my assistance to the health system in the prisons. This will better the conditions of the health of inmates.

\section{Reduction in Vocational Training Experts}

Majority of the participants described imprisonment as an avenue through which professionals were siphoned from the educational institutions. They alleged that this situation was inimical to the continuous training of young professionals. Participants were of the view that the incarceration of entrepreneurial training experts and teachers denied the up-andcoming productive youths the relevant knowledge.
$\mathrm{ABC}$ 62: Government stands to lose one of the foundation builders of professionalism that is the initial training necessary for professional excellence.

ABC 55: My business was potentially training twenty (20) apprentices who were going to become professionals, but this has been halted by my imprisonment.

ABC 59: At this time, after forty (40) years, I believe I would have trained hundreds of professional mechanics, who by now, would have been contributing to the country's economic growth.

In spite of the claim that imprisonment of professionals could lead to reduction in the number of trained youths, participant $\mathrm{ABC} 62$ presented a different dimension of his experiences in his prison life. He reported that through his imprisonment, he had the opportunity to develop his sewing skills, which could inure to the benefit of the youths and minimise the issues of unemployment. This was how he presented his case:

ABC 62: My imprisonment has had a positive impact on my personal development. with my new skill, I intend to train as many people as I can into becoming productive tailors and reduce unemployment.

\section{Rise in Unemployment among the Youths}

Participants described their incarceration as the cause of incessant increase in youth unemployment. They lamented that the imprisonment of seasoned professionals was denying the youth the acquisition of entrepreneurial and professional knowledge and skills. Participants claimed that failure to train the youth had adverse effects on the entire economy.

ABC 66: My imprisonment has caused a rise in the number of unemployed youths by the numbers of people I used to hire to work for me.

ABC 74: As was mentioned earlier, I would have, by now, been established as a well- 
developed individual available in my professional field. The government had lost the impact I would have made if I had had my freedom to work and develop myself. Table 1 reflects most of the issues involving the impact of imprisonment of active labour on human capital.

Table 1. Frequency Table on the Impact of Imprisonment of Active Labour on Human Capital

\begin{tabular}{|l|l|l|l|l|l|}
\hline Statement & N & Mean & STD Dev & Variance & Rank \\
\hline Reduction in active labour & 108 & 4.00 & 0.538 & 0.289 & 1 \\
\hline Reduction in vocational training experts & 108 & 3.57 & 0.909 & 0.826 & 2 \\
\hline Rise in unemployment among the youths & 108 & 2.71 & 1.228 & 1.508 & 3 \\
\hline
\end{tabular}

Source (Field Data, Priscilla Brobbey, July, 2020)

Table 1 presents findings on the impact of imprisonment of active labour on human capital. Ranking first with mean score of 4.00 , standard deviation of 0.538 and variance of 0.289 was to the statement, "reduction in active labour". The second ranking with mean score of 3.57 , standard deviation of 0.909 and variance of 0.826 went to the statement, "reduction in vocational training experts". The statement, "rise in unemployment among the youths", came third with mean score of 2.71 , standard deviation of 1.228 and variance of 1.508 .

As observed from the results, participants bemoaned the impact of their incarceration on human capital development of Ghana. They mentioned reduced active labour, reduced number of vocational training specialists and increased unemployment among the youths.

\section{Discussion}

All participants described the imprisonment of perpetrators of crime as a factor that militated against the smooth development of human capital and regarded imprisonment as an impediment to realisation of the full potential of the benefits of human resources of convicts as well as their children. This is consistent with [34] that parental imprisonment results in considerably greater rate of senior high school dropout. They labelled reduction in human capital and vocational training experts as the causes of rise in unemployment among the youths. This is in line with [35] that an extra year of imprisonment leads to $3.6 \%$ decline in post-release employment.
A few participants claimed that although their incarceration had impacted the sectors of education and health negatively in the larger society, they had been able to use their knowledge to help other inmates. This is consistent with [36] that prisoners must be treated humanely by engaging and paying them for their work done while in custody.

\section{Reduction in Active Labour}

Participants described their imprisonment as one of the ways of robbing the economy of productive labour and asserted that this situation was injurious to the development of the economy. For that matter, it has been suggested that severally that the current 11 million prisoners be engaged in productive ventures, such as manufacturing, for their own benefit and that of their respective economies $[37,38]$. Some of them emphasised that if this situation continued, the government would pay dearly for it by incurring the cost training other citizens to replace the incarcerated professionals and claimed that this situation had dire consequences for both the government and the economy in general. This supports the claim of [39] that skilled labour keeps the economy in shape through its instrumentality in the conversion of raw materials to finished products for human consumption.

\section{Reduction in Vocational Training Experts}

Majority of the participants described imprisonment as an avenue through which 
professionals were siphoned from the educational institutions and alleged that this situation was inimical to the continuous training of young professionals, which could result in economic losses to the state. Participants were of the view that the incarceration of entrepreneurial training experts and teachers denied the up-and-coming productive youths the relevant knowledge, which could cause economic hardships. This situation can lead to rise in distress, anxiety, melancholy and feeling of dependency.

\section{Rise in Unemployment among the Youths}

Participants described their incarceration as the cause of incessant increase in youth unemployment. This unemployment situation can lead to rise in distress, anxiety, melancholy, depression and feeling of despondency and dependency. They lamented that the imprisonment of seasoned professionals was denying the youth the acquisition of entrepreneurial and professional knowledge and skills and claimed that failure to train the youth could have had adverse effects on the economic growth of the country.

\section{Conclusion and Recommendations}

The paper, therefore, arrives at this simple conclusion that modern prison management is complex. For that matter, the prisons industry in Ghana must carefully develop the ability to establish a dichotomy between the security and profit motives of the prisons to guide it. The onus is on the administrative structure of the prison to help in system building to enhance the rehabilitation service capacity of inmates. This will minimize government expenditure from taxpayers' coffers on convicts and possibly reduce recidivism to the barest minimum in Ghanaian society.

For convicts to contribute to their own socioeconomic lives, the authorities of the prison industry must be managed by a team of diverse professionals. Professional convicts require labour management experts to guide them in order to put their skills to productive use. Nonprofessional convicts need to be equipped with relevant skills so that they can be socioeconomically sound. Prison authorities must look out for external funds, external capacity builders, and labour management experts for efficient and productive use of prisoners' labour. Prison authorities must liaise with the labour management experts so that professional ex-convicts are productively engaged in order to contribute to economic growth and reduce recidivism.

The paper recommends that researchers must adopt the 'Inside Skills Acquiring Support Model', developed by the author, as their theoretical framework for similar future studies.

\section{Conflict of Interest}

The researcher has no conflict of interest in the conduct of this study.

\section{Acknowledgements}

I am very grateful for the supportive guidelines of my supervisor in the person of Prof. Emmanuel Tweneboah Senzu, his absolute commitment, and selfless guidance to carry out this research project successfully. 


\section{References}

[1] OECD (2020). The value of people. OECD Insights: Human Capital.

[2] Schultz, T. W. (1993). Investment in human capital. The American Economic Review, 51 (1) 1-

17. https://www.jstor.org/stable/1818907.

[3] Johnes, J., Portela, M. \& Thanassoulis, E. (2017). Efficiency in education. Journal of the Operational Research Society, 68, 331-338 https://doi.org/10.1057/s41274-016-0109-z.

[4] Chowdhury, M. N. M., Uddin, M. J., Uddin, N. \& Uddin, S. (2018). The human capital development and economic growth in Bangladesh. Journal of World Economic Research, 7(2), 52-63 doi:10.11648/j. jwer.20180702.12.

[5] Diebolt, C. \& Hippe, R. (2019). The long-run impact of human capital on innovation and economic development in the regions of Europe. Applied Economics, 51 (5), 542-563. https://doi.org/10.1080/00036846.2018.1495820.

[6] Isola, W. A. \& Alani, R. A. (2007). The human capital development and economic growth: Empirical evidence from Nigeria. Asian Economic and Financial Review, 2 (7), 813-287 http://www.conscientiabeam.com/pdffiles/eco/3/2(7)\%20813-827.pdf.

[7] Barra， C. \& Zotti， R. (2016). Investigating human capital development - growth nexus: Does the efficiency of universities matter? International, regional Science Review. Retrieved from: https://doi.org/10.1177/0160017615626215.

[8] Dauda, R. (2011). Effect of public educational spending and macroeconomic uncertainty on schooling outcomes: Evidence from Nigeria. Retrieved from:

http://www.scielo.org.pe/scielo.php?pid=S2077$18862011000200002 \&$ script=sci_arttext\&tlng=en.

[9] Hanushek, E. A., Schwerdt, G., Woessmann, L. \& Zhang, L. (2017). General education, vocational education, and the labour-market outcomes over the life-cycle. Journal of Human Resources, 52, 1 (winter), 48-87

http://jhr.uwpress.org/content/52/1/48.short.

[10] Psacharopoulos, G. \& Patrisos, H. A. (2018).

Returns to investment in education: A decennial review of global literature. Policy Research Working Paper 8402, World Bank, Washington, DC https://doi.org/10.1080/09645292.2018.1484426.

[11] Poças, A. I. (2014). Human capital dimensionseducation and health -and economic growth. Advances in Business-Related Scientific Research Journal, 5(2), 111-120 http://hdl.handle.net/10314/2417.

[12] Ramos, R., Surinach, J. \&Artis, M. (2012), Regional economic growth and human capital: the role of over-education. Regional Studies, 46 (10), pp.1389-1410.

https://dx.doi.org/10.1080/00343404.2012.675140.

[13] Hanushek, E. A. (2016). Will higher education improve economic growth? Oxford Review of Economic Policy, 32(4), 538-552 http://hanushek.stanford.edu/sites/default/files/publi cations/Hanushek\%202016\%200xf\%20Rev\%20Eco n\%20Policy\%2032(4).pdf.

[14]Ebenehi, A. S., Rashid A. M. \& Bakar, A. R. (2016). Predictors of career adaptability skill among higher education students in Nigeria. International Journal for Research in Vocational Education \& \& Training, 3 (3), 212-229 http://hdl.handle.net/10419/149570.

[15] Eigbiremolen, O. G. (2014), Human capital development and economic growth: The Nigeria experience. International Journal of Academic Research in Business and Social Science, Vol.4, issue 4, 25-35

http://citeseerx.ist.psu.edu/viewdoc/download?doi=1 0.1.1.686.4006\&rep=rep1\&type=pdf.

[16] Walters, S. T., Clark, M.D., Gingerich R. \& Meltzer, M. L. (2007). A guide for probation and parole: Motivating offenders to change available. http://www.doc.state.nc.us/dcc/EBP/guideforprobati onmotivatchgnic.pdf.

[17] Kolind, T., Frank, V.A., \& Dahl, H. (2010), Drug treatment or alleviating the negative consequence of imprisonment; A critical view of prison-based drug treatment in Denmark Vol.21, Issue 1, p.43-48 https://doi.org/10.1016/j.drugpo.2009.03.002.

[18] Gatotoh, M. A., Omulema, E. B., and Nassiuma, D. (2011), Correctional attitudes: An impetus for paradigm shift in inmate rehabilitation. 
International Journal of Humanities and Social Science, $\quad 1(41), \quad 263-270$. https://www.uonbi.ac.ke/openscholar/sites/default/fil es/augustine_gatotoh/files/correctional_attitudesan_i mpetus_for_a_paradigm_shift_in_inmate_rehabilitat ion.pdf.

[19]Lipton, D., Martinson, R., and Wilks, J. (1975), The effectiveness of correctional treatment: A survey of treatment evaluation strategies. New York: Praeger https://catalog.princeton.edu/catalog/SCSB3549390 .

[20] McGuire, J. (Ed.) 1995, Reducing reoffending: Guidelines from research and practice. John Wiley \& Sons https://psycnet.apa.org/record/1995-98528-000. [21]Cullen, T. F., and Gendreau, P. (2000), Assessing correctional rehabilitation: Policy, practices, and prospects. National Institute of Justice, Rockville, MD 202849. USA http://www.publicsafety.gc.ca/lbrr/archives/cnmcspleng/cn34984-v3-109-175-eng.pdf.

[22] Gibbs, J. P. (1986), Deterrence theory and research. In G.D. Melton (ed.), The law as a behaviourial Instrument: Nebraska Symposium on motivation, Vol.33, pp. 87-130. Lincoln, NE: University of Nebraska Press https://psycnet.apa.org/record/1989-25780-001.

[23] Stohr, M.K. \&Zupan, L. L. (1992). Street-level Bureaucrats and Service provisions in Jails: The failure of officers to identify the needs of inmates. American Journal of Criminal Justice, 16(2), 75-94. https://www.ojp.gov/ncjrs/virtual-

library/abstracts/street-level-bureaucrats-andservice-provision-jails-failure.

[24] Stohr, M., Lourich N. and Wood, M. (1996), Services versus security concerns in contemporary Jails: The general testing difference in training topic assessment. Journal of Criminal Justice, Vol.24. Issue 5, pp. 437-448 https://doi.org/10.1016/00472352(96)00030-X.

[25] Paboojian, A., Raymond, H. C., Teske Jr. (1997), Pre-services correctional officers: What do you think about treatment? Journal of Criminal Justice. Vol.25, Issue 5, pp.425-433 https://doi.org/10.1016/S0047-2352(97)00025-1.

[26] Moon, B. \& Maxwell, R. S. (2004). Assessing the correctional orientation of corrections officers in
South Korea. International Journal of Offender Therapy and Comparative Criminology, 48(6), 729743 https://doi.org/10.1177/0306624x04266681. [27] Rule, W. R, \& Gandy, G. L. (1994). A thirteenyear comparison in patterns of attitudes counselling. Adolescence, 29, 575-589 https://psycnet.apa.org/record/1995-10423-001. [28] Poole, E., \&Regoli, R. (1980), Role stress, custody orientation and disciplinary actions: A study of Prison Guards. Criminology 18:215-26 https://doi.org/10.1111/j.1745-9125.1980.tb01360.x. [29] Kantorowicz-Reznichenko, E. (2015), Reducing prison costs through prison labour: A Law and Economics approach. https://dx.doi.org/10.2139/ssrn.2858873.

[30] Shea, E (2007). Why work? A study of prison labour in England, France and Germany. Berlin: Duncker \& Humblot. http://hdl.handle.net/11858/00001M-0000-002E-47EB-C.

[31] Tak, P. J. P. (2008). Prison policy, prison regime and prisoners' rights in the Netherlands under the 1998 Penitentiary Principles Act. In Prison Policy and Rights and Prisoners' Rights: Proceedings of the colloquium of the IPPF (2008), 457-492.

https://internationalpenalandpenitentiaryfoundation. org/Site/documents/Stavern/23_Stavern_Report\%20 Netherlands.pdf.

[32] Monavarian, A., Asgari, N., \& Ashena, M. (2007), Structural and content dimensions of knowledge-based organization. Tehran, The National Conference on Knowledge Management, 10-20.

[33] Rezayian, A., (2005). The basis of organization and management.

[34] Henkhaus, L. E. (2019). The child left behind: Parental incarceration and adult human capital in the United States. AEA Papers and Proceedings, 109, 199-203.

https://www.aeaweb.org/articles/pdf/doi/10.1257/pa ndp.20191092.

[35] Mueller-Smith, M. (2015). The criminal and labour market impacts of incarceration. Retrieved from: www.psc.isr.umich.edu.detail. 
[36] McGrew, A. \& Hanks, A. (2017). It's time to stop using inmates for free labour. Retrieved from: www.talkpoverty.org/2017.

[37] Archibong, B. \& Obikili, N. (2020). Prison labour: The price of prisons and the lasting effects of incarceration. African Economic History Working Paper Series, $\quad 52, \quad 1-95$. https://papers.ssrn.com/sol3/Delivery.cfm/SSRN_ID 3775731_code2329399.pdf?abstractid=3635484\&mi rid $=1$.
[38] Chapman, I. (2019). Prison inmates are fighting California's fires, but are often denied firefighting jobs after their release. CNN.

[39] Amadeo, K. (2020). What is human capital? Definitions, examples and impact of human capital. U.S. World Economies.

http://thebalance.com/human-capital-definitionexamples-impact-4173516. 